\title{
Do Changes in the Economic Role of States through Privatization matter?: The Brazilian Case
}

\section{TÖRÖK}

The University of Debrecen, Faculty o Engineering, Department of Engineering Management and Enterprise, Visiting Lecturer, Qualified Lecturer, Chamber of Hungarian Auditors, Managing Director, Hajdúsági-Flott e-mail:dr.torok.laszlo@eng.unideb.hu

Abstract. In market economies, the subject of scientific research is the extent to which the state can contribute to the sustainability of development. However, the question is to know where the boundaries of the market and the role of the state lie. The study briefly introduces different views of the state's economic role and how states have changed the proportion of their entrepreneurial assets. Among these, it highlights privatization, which is one of the significant segments of today's economic policy practice at both micro and macroeconomic levels. It then describes Brazil's economic circumstances that led to the formulation of a proper size privatization program. Finally, the socio-economic factors that, according to the author, make the realization of Brazilian privatization plans uncertain presented.

Keywords: government debt; budget deficit; privatization; Brazilian economy.

\section{Introduction}

The role of states in economic life has always been one of the critical areas of economics research. The starting point of these surveys is what kind of public services the state has to provide in a given national economy, what tools to use in this task supply and the proportion of entrepreneurial assets among its assets. The answer to the question was what kind of economic policy view had the political elite at the moment in the national economy concerned. The degree of economic involvement of the state is a complex phenomenon. The study of this is part of economics, and its theoretical aspects of efficiency can be deduced from general economics items according to [1]. Different trends have emerged in the history of economic theory about the need for state involvement and state intervention in the economy. Advertisers claiming the need for state involvement have based their view that this is necessary because the market alone cannot function effectively. According to some researchers, such as [2], there are market failures in an advanced national economy, which is why the state must intervene. In this case, the state implements a broad role by a combination of direct and indirect assets. The opponents of state involvement and intervention in the economy also developed an extensive camp. Among them, the work of [3] noted, which emphasizes that government policy can cause destabilization in the economy, and thus strengthen the role of the state as modest as possible. From topic, the economic role of the state is essential. A critical slice of this is the proportion of state- 
owned enterprises within a given national economy. Looking at the economic history of the economies of developed economies, we are witnessing fluctuations in this respect. Looking back at the number of state interventions for a few decades, we see that it has weakened from time to time and then strengthened. These fluctuations manifested in several ways. In doing so, the consolidation of stateowned enterprises, the nationalization of private companies and the subsequent (re) privatization of state-owned enterprises and finally, the emergence of state asset management procedures can be observed. It can be concluded that the strategies of the state's economic role are continually changing. In the future, the state's entrepreneurial property management can be pursued in two directions for developed and developing countries. One direction may be that economic policy will only focus on the utilization of public funds. However, it follows that the managers of state-owned entrepreneurial assets will be the real owners of shares in the future. If this farming is productive, then it will be possible to finance financially beneficial goals for the whole society from the gains. Contrary to the previous one, the intention to privatize state assets could be intensified, which would indicate that the state is gradually withdrawing from its economic role. It seems reasonable to assume that changing an entrepreneurial property (which may mean privatization on the one hand and nationalization on the other) is an appropriate tool for dealing with the current problems of a given national economy. It is particularly important when a radical transformation of the socio-economic system is on the agenda in a country. A significant transformation of a socio-economic system could be to increase the state's entrepreneurial wealth through nationalization or, on the contrary, to reduce it by privatization.

The aim of the study is not to present in detail the macroeconomic factors that force a significant change in the country's economic policy. However, without at least sketching out these factors, Brazilian macroeconomic plans (above all, privatization) that will be presented later in the thesis would be challenging to understand.

\section{The weight of privatization in the global economy}

Undoubtedly, in global economy, it is not the most relevant process to privatize public entrepreneurial property. In the public consciousness of the economics profession, the picture is that after the privatization in the systemic socialist countries, this process has lost its significance. However, if we examine the data of the value of global privatization, as shown in the following figure, we come to another conclusion. 


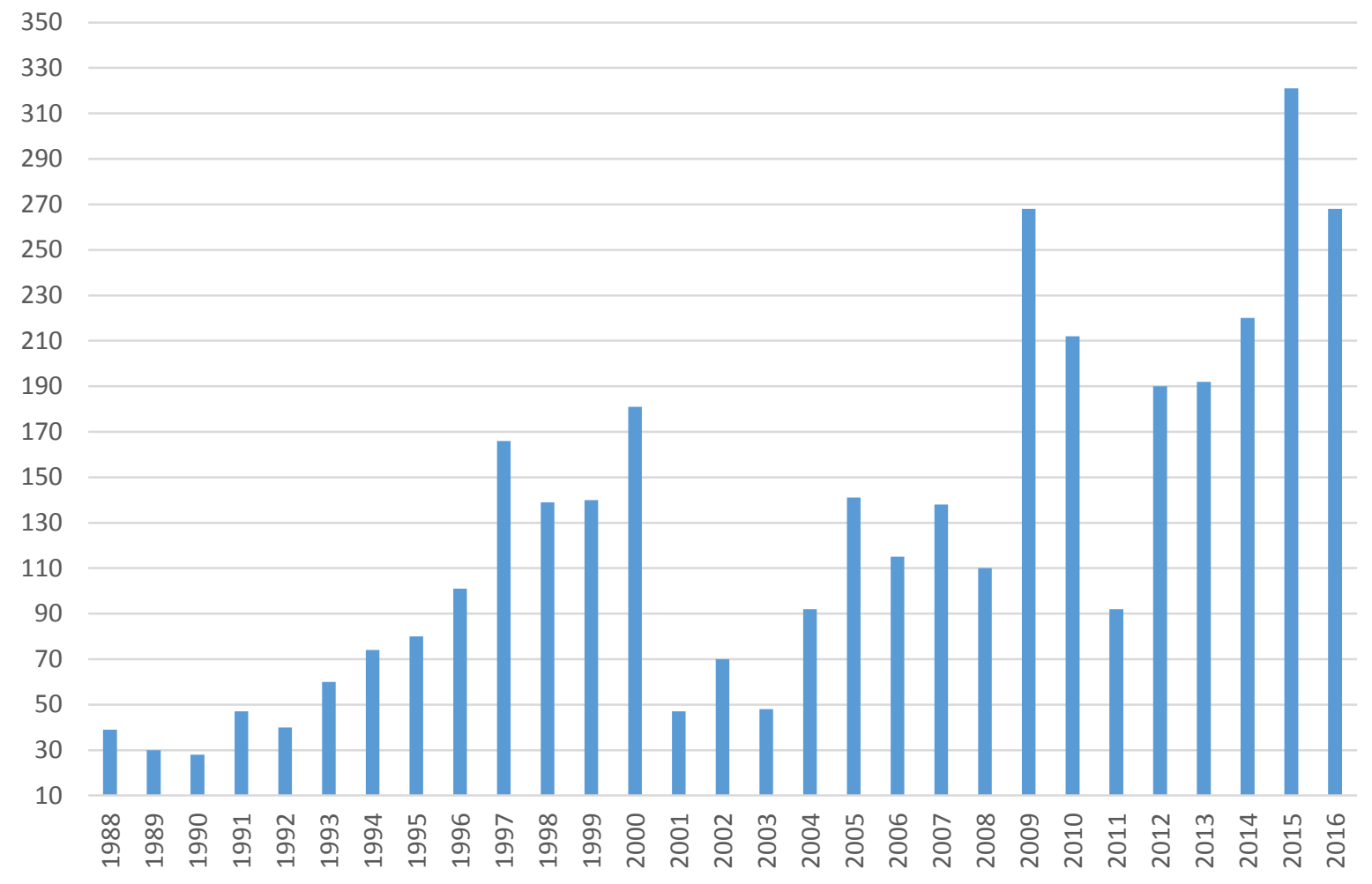

Figure 1. Global privatization revenues (1988-2016), in billions of US dollars [4]

The chart clearly shows that privatization revenues rose steadily from 1988 to 2000, from USD 39 billion to USD 180 billion. During this period, the privatization of state-owned enterprises of the former Central-Eastern European socialist countries took place. Subsequently, there was a significant downturn, and from 2004 onwards, another dynamic growth observed to 2016. The most considerable privatization value was generated in 2015, amounting to $\$ 321$ billion, equivalent to Hong Kong's 2016 GDP. The description of the previous data served to illustrate that privatization is not an insignificant manifestation of today's economic processes.

\section{The sale of state property is micro- and macroeconomic aspects}

Privatization usually examined in a microeconomic approach. It is evidenced by the fact that in the analysis of privatization, most of the literature studies examine privatization from a microeconomic point of view. The central aspect of the analysis is that the efficiency of the operation of former stateowned company in the process of privatization. Most of the studies looked at the changes in the efficiency of public companies in the former socialist countries after privatization. The main conclusion of these studies was that after the privatization, the company's productivity improved. Labour productivity increased significantly $(+7.3 \%)$ in privatized companies. In contrast, in stateowned enterprises, productivity decreased by $0.2 \%$ over the same period, according to [5]. A similar statement made in [6] study on the global analysis of privatization.

Other considerations are essential in the macroeconomic approach to privatization. The first thing to mention is that privatization revenues can effectively improve the state budget balance. It is especially 
crucial if the state has a high budget deficit. It follows from this that the government has liquidity difficulties which it can mitigate if it receives market value for its public assets. Not every country uses this opportunity. For example, Ireland did not sell public business assets during the financial crisis [7]. In this respect, it is also of great importance that the privatization consideration comes from a foreign or domestic investor. Their difference highlighted in their [8] study.

The next important link is that if a privatized private company can operate more efficiently than before, it will provide a positive, net return on public finances through increased tax and contribution payments. Another noteworthy aspect is that the privatization fee received by the state - if it is not used to repay public debt - appears on the aggregate demand side of the national economy concerned, thus contributing to the growth of the national economy. In the case of the use of government revenue to repay public debt, it can generate significant socio-economic benefits. The empirical fact that the economic growth of the given national economy becomes the relevant effect of the business operation that becomes more efficient by privatization. It is reflected in faster GDP growth. Finally, it is necessary to emphasize the macroeconomic impact of privatization that, at the start of the change of ownership, new, privately-owned, typically redundant, will be implemented. After that, however, the increase in the number of employees is mostly based on global economic experience. Overall, with the completion of privatizations, the unemployment rate trend has declined in the affected national economies [9].

The implementation of the micro- and macro-economic benefits presented in connection with privatization plays an essential role in the dynamism of the growth of a highly indebted national economy with low international competitiveness. Nowadays, Brazil's economy has these two essential negative economic characteristics. It follows that the privatization tool should be used to boost the country's economic growth.

\section{Reasons leading to a change in Brazil's economic policy}

The most important macroeconomic factors are leading to the economic turnaround presented in the following analysis of [10]. One of Brazil's most important economic challenges is its modest productivity growth, which undermines the country's growth potential. At the same time, the weak logistics infrastructure, the different tax systems of individual federal states, and state subsidies for certain companies make it possible for less efficient companies to survive permanently. It leads to a decrease in the average level of productivity in the Brazilian economy. The business environment is not sufficiently entrepreneurial; it should be made, among other things, by reforming the tax system. Significant fiscal adjustment is also needed because the government's budget balance has been in a significant deficit in recent years. Productivity and potential economic growth in the Brazilian economy have only risen slowly, while real public spending has increased sharply. The level of public spending as compared to GDP in less than 30 per cent of the 1980s rose to about 40 per cent by 2017. However, public investment - including infrastructure - investments, declined, falling to less than 0.7 per cent of GDP last year. The following figure (2) shows the state budget deficit: 
International Journal of Engineering and Management Sciences (IJEMS) Vol. 4. (2019). No. 4

DOI: 10.21791/IJEMS.2019.4.13.

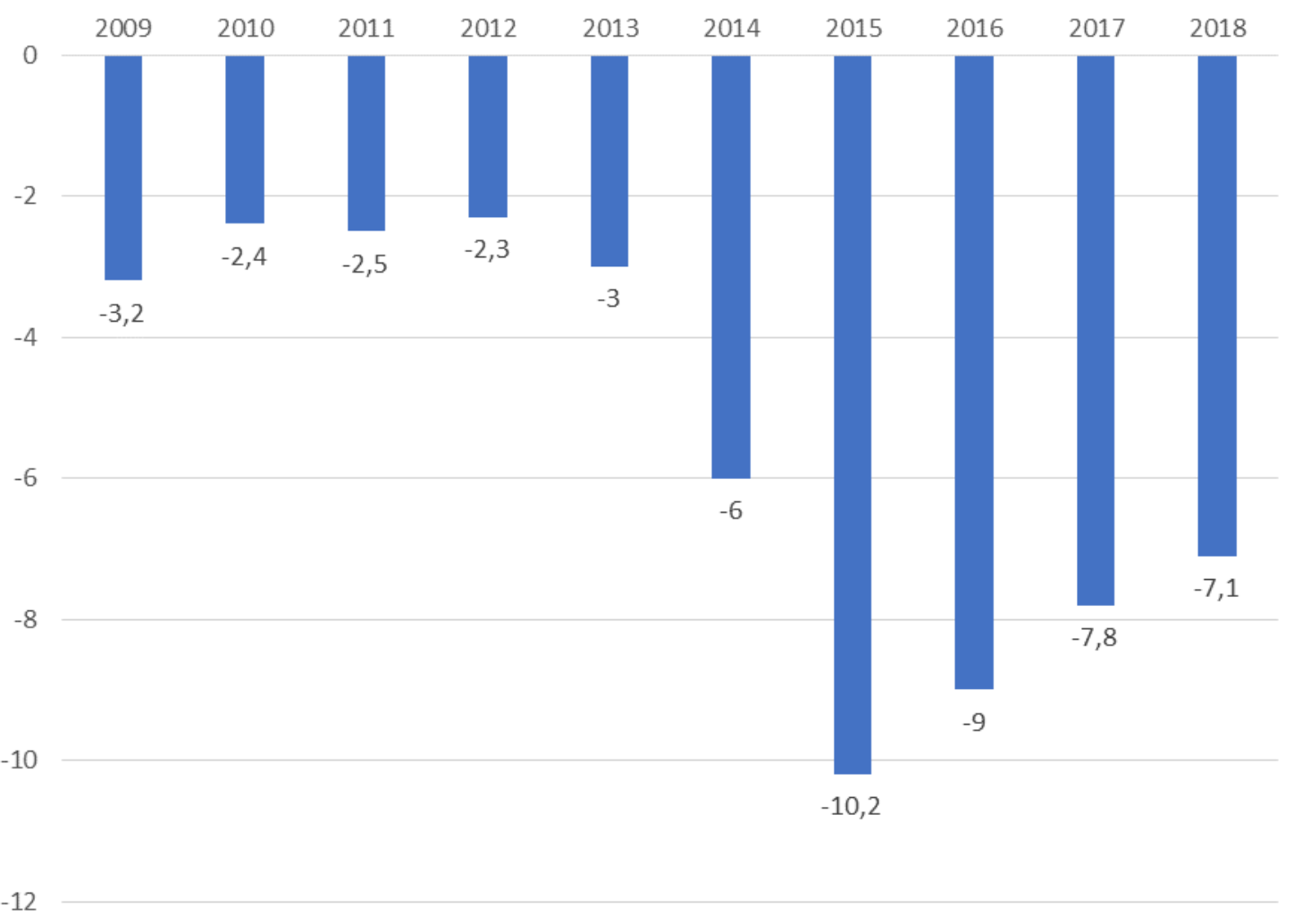

Figure 2. Brazil's budget deficit (2009-2018) as a percentage of GDP [11]

The decline in GDP in 2015 and 2016, as well as the subsequent fragile economic upturn, had an impact on tax revenues, leading to a deterioration of the primary balance by more than six percentage points of GDP in 2016, followed by a high level of mortality after that. It made a decisive contribution to the rate of public debt to GDP in 2010, from 52\% in 2010 to over $77 \%$ in 2018. Its rate reached the 70 percent psychological limit in 2017, which most credit rating agencies consider being critical for emerging countries. Furthermore, according to some estimates, taking into account the implicit state liabilities and guarantees for public corporations, banks and pension funds, the amount of Brazilian public debt is already around one hundred percent of GDP, making Brazil one of the most indebted countries in the Latin American region. The following figure (3) illustrates the evolution of gross government debt without implicit state liabilities: 


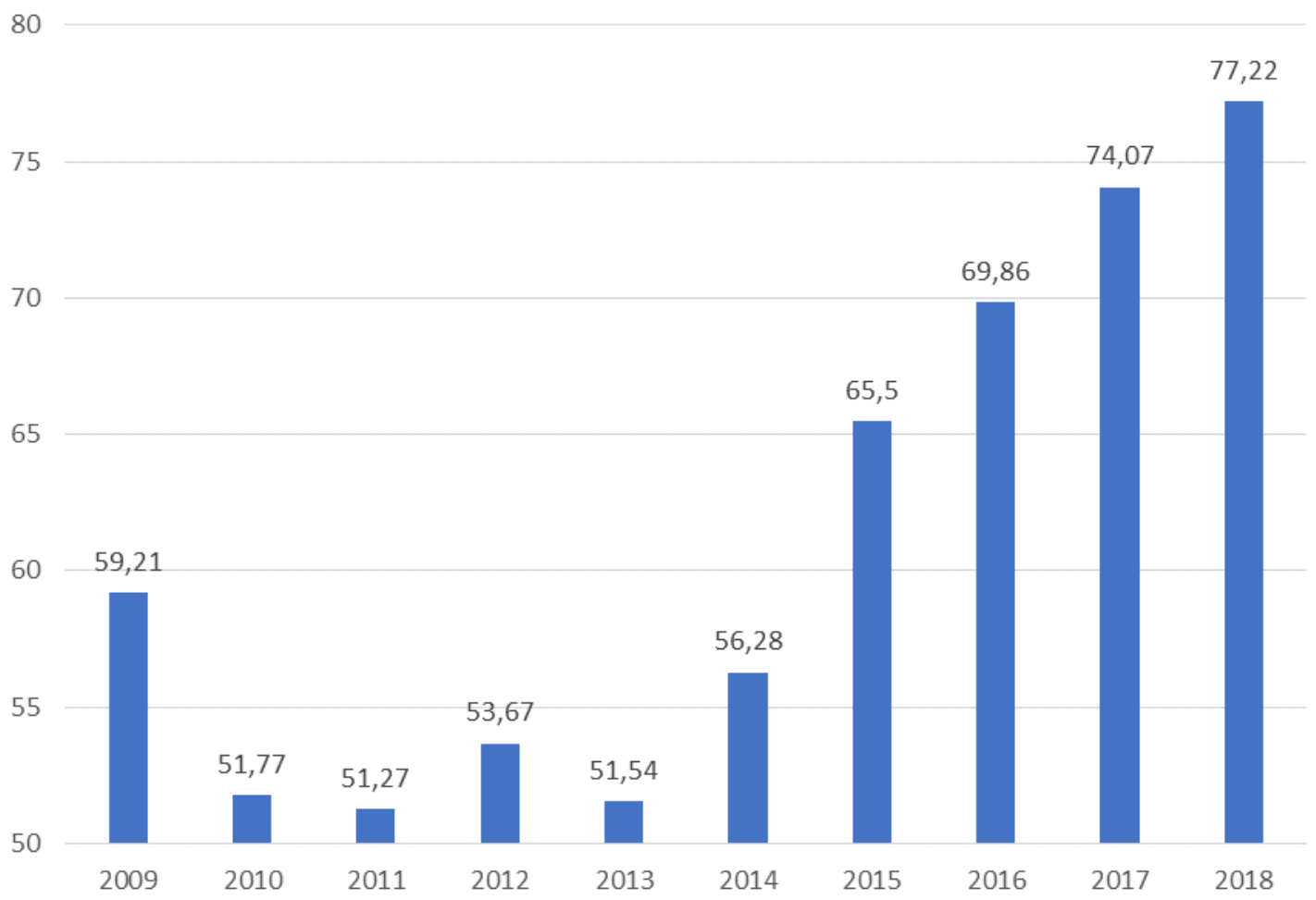

Figure 3. The evolution of government debt in Brazil (2009-2018) as a percentage of GDP [11]

An optimal strategy for dealing with public debt can be elaborated. The aim of the debt management strategy is, in general, to realize this critical task of the debt manager in the most efficient way within the current framework of economic policy, making the best use of debt financing alternatives. If this happens, a debt structure with the best cost/risk ratio can be realized in the long run. It is not the purpose of the study to develop such a strategy, but some guidelines can be formulated to deal with the Brazilian state budget and debt financing. The system of social security, public servants, various state subsidies and tax exemptions needs to be significantly modified. By alleviating the burden on public budgets, these spending cuts can provide space for other, more resourceful ways of spending public funds. Spending cuts must have a minimal impact on the weaker sections of the country. Tax reforms can also include measures that not only improve the business environment but also help to reduce the high socio-economic inequality in the country, according to [10].

\section{Basics of Brazil's privatization strategy}

It is challenging to spell out precisely what specific factors might be in favour of Brazilian privatization ideas, but certainly one of them is the need to reduce public debt. In point 2 , the micro and macroeconomic mentioned overall positive effects of the privatization of public companies. In the following, some specific components detected, not necessarily in the order of importance, that strengthens the constraint of privatization. One of the relevant factors in favour of privatization is that no country in the American continent has more State-Owned Enterprises than Brazil. According to the OECD (Organization for Economic Cooperation and Development), there are more state-owned 
enterprises in Brazil than in any other member state. The country ranks first in the statistical ranking with 418 state-owned enterprises, while Hungary ranks 370 in second place, according to the OECD. There are only 78 companies with this status in Mexico. There are 39 SOEs in Colombia, and the least, only 25 state-owned enterprises in Chile. Although Argentina is not a member of the OECD, there are only 41 companies in the state. So, it is in Brazil to privatize it. A large number of Brazilian stateowned enterprises does not necessarily justify their privatization as a strategic issue. A more significant factor here is that in the 2000s, the international competitiveness of Brazilian companies has decreased significantly. In recent years, unit labour costs have risen significantly in Brazil (wages have risen faster than productivity), and this indicates that competitiveness (at least as a cost factor) has deteriorated internationally, according to [12] study. It follows from this statement that it would be essential for Brazilian companies to include strategic elements in their operation that would increase their international competitiveness. The privatization would be an appropriate tool. Substantially, the privatization of Brazilian state-owned enterprises could significantly reduce the country's increased debt.

\section{Privatization is a significant potential factor in reducing Brazil's public debt}

In Brazil, the budget deficit is still so high today that, without government intervention, public debt would remain on an ever-increasing path even if the current global economic activity stagnated for a long time. It is, therefore, essential to stop and reduce the growth of public debt.

\subsection{Is there any optimum for public debt?}

First of all, is it essential to answer the question of what is the optimal level of public debt compared to GDP? There is no exact rule in economics on the optimal rate of debt for a given national economy. The 60 percent numerical ratio in the Maastricht Treaty of the European Union is a product of a general agreement, a kind of alignment. The 60 percent rate is by no means the optimum. Several studies, including the work of [13], consider dangerous levels in developing countries to be 40 , and in the case of developed countries, 60 per cent. As shown in Figure 2, Brazil reached this 60 percent critical government debt level in 2015 and continued to grow in the following years. The current political leadership of the country has declared that it is planning to significantly reduce the country's accumulated debt at an accelerating pace.

\subsection{Extreme interest payment after public debt}

Why is government debt reduction substantial in Brazil? The amount of government debt affects the amount of interest expense to be paid. In a country with a more substantial debt position, interest expenditure is also higher. Interest rates are influenced by risks, expectations, and risk premia. Brazil is paying the fourth highest interest rate in the world after its debt. A study of 183 countries showed that Brazil paid 7.63 percent of its annual GDP in 2016 as a debt burden, according to [14]. 
It is an extremely high value, with the direct consequence that in the long run, government debt and the interest to be paid on it will negatively affect the capital accumulation of Brazil and the consumption of future generations. The high public debt interest payment obligation will slow down the country's potential output and consumption growth in the long run. It is due to the detrimental effects of the taxes levied on interest payments (experienced in all national economies) and the displacement of capital, thus hindering capital accumulation. However, the unprecedented global money generation recently generated by the world's central banks, despite the ever-decreasing interest rates, interest payments place enormous burdens on Brazil's public finances. Although the money supply in the global economy had a positive impact on the cost of financing, Brazil is now spending "only" 6.51 percent of its annual GDP on interest payments.

\subsection{Brazil's privatization portfolio}

In 2017, the previous government drafted a privatization plan, that failed due to the change of government. However, the new government has also planned the privatization of state-owned enterprises by market methods. The 2017 Privatization Portfolio forms the basis for the current draft but contains significant changes compared to it. The study does not provide a detailed description of the portfolio; its main sectors presented. As part of this, they intend to privatize 57 state and federal companies, hoping to sell tens of billions of dollars of state revenue. The most significant sold stateowned enterprises are fourteen airports, eleven electricity networks, fifteen harbour terminals and the Brazilian Mintage, and the privatization of two public highways based on [15].

The new Brazilian government has substantially redesigned, expanding this earlier privatization plan. The intention is to reduce the country's huge public debt by about 20 per cent, mainly through the implementation of the privatization plan described above and partially amended. At the end of 2017, the country's sovereign debt denominated in US dollars at 1.467 .8 thousand billion, which should be reduced by 20 per cent, which is approximately $\$ 300$ billion. Compared to the previous plan, at least 100 public companies are planned to be privatized or closed. Company closure and liquidation indirectly can reduce public debt. Losses from loss-making state-owned enterprises will eventually have to be paid by the state to the budget. If the loss-making state-owned enterprises liquidated, they will also lose their 'production' of losses, so the central budget will be exempt from replenishing them. The result of this process will be that "lost" losses will automatically reduce public debt. There is little information on how the grandiose privatization plan would affect the two most valuable Brazilian companies, the oil industry Petrobrast and the Eletrobrast energy companies/.

\subsection{Predicting public debt without state intervention}

In macroeconomics, the rate of economic growth may exceed the amount of real interest paid on government securities. In this case, the state's indebtedness can stabilize without any intervention. This condition occurs regardless of the initial amount of the debt. However, this situation can not happen in Brazil. 


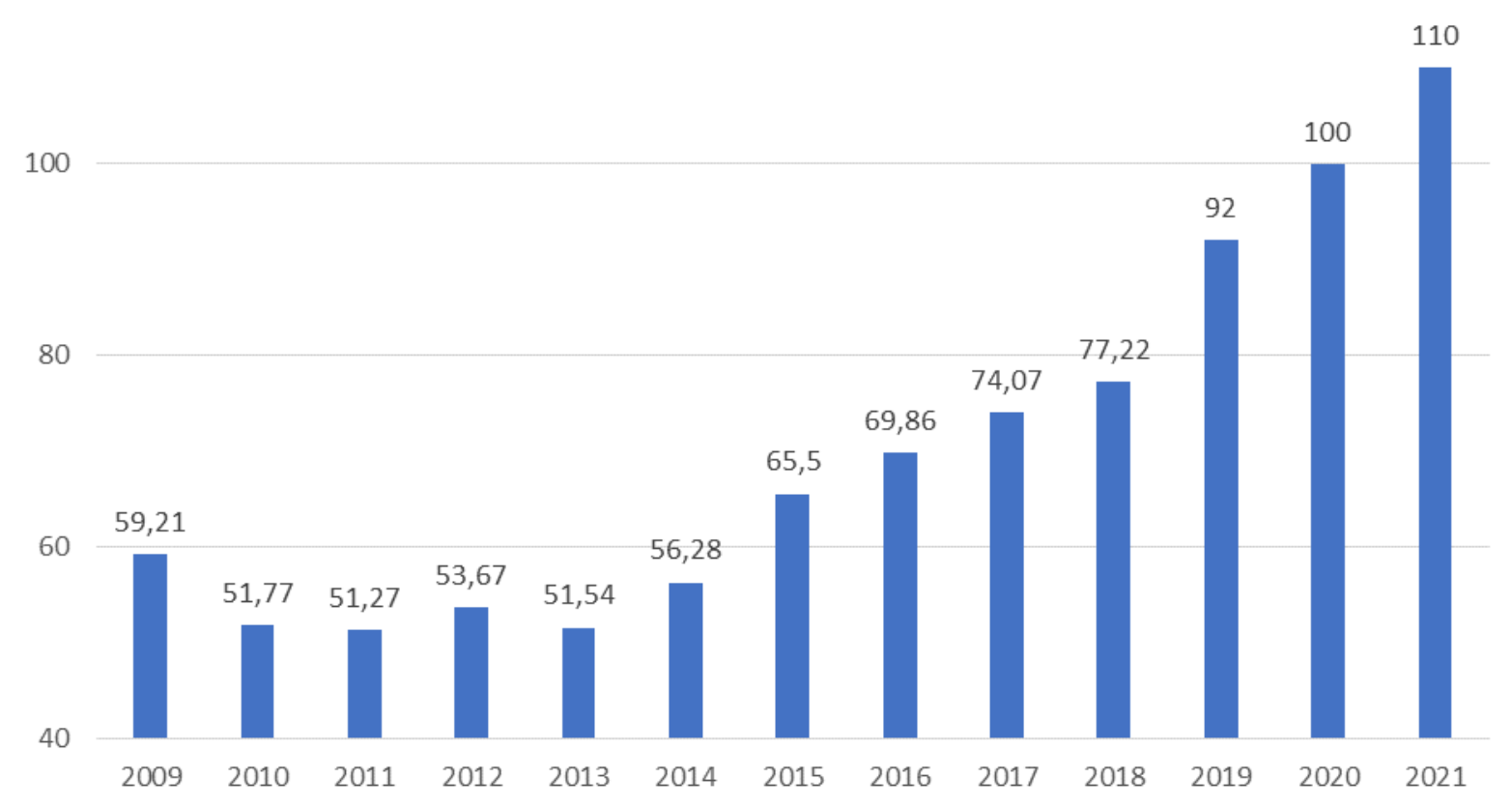

Figure 4. Expected development of government debt in Brazil until 2021 as a percentage of GDP [11]

By the end of 2019, Brazil's public debt is projected to exceed $82 \%$ of GDP, which is a dangerously high level for a developing country that is a raw material exporter. Moreover, if the external world economic environment becomes unfavourable, , the public debt will rise rapidly and drastically, which can easily trigger debt spirits in the country. High and rising debt will only be financed more and more, and rising interest expenditure will further increase the budget deficit. This situation typically occurs in a national economy, when it is also necessary to borrow interest on payments, and Brazil has characterized for years. Since Brazil is in a fortunate position to finance its public debt primarily by domestic private sectors, some of the public debt can be reduced by fluctuating inflation and hence taxing savings. The easy way to flourish sovereign debt and private wealth are to devalue the domestic currency. This year, Brazil's real value has fallen by nearly 13 per cent against the dollar, which is not an outlier, but in no way a normal devaluation. Moreover, it is a political decision to make the consequences of such an economic policy for decision-makers.

\section{Conclusions}

The current economic situation in Brazil is difficult and complicated. There is no doubt that the public debt of more than eighty per cent of GDP nowadays has to be tried to reduce; otherwise, it will only be financed with increasing costs. An optimal solution to reduce public debt in macroeconomic terms would be to increase the Brazilian economy to a very high output level. In this case, dynamically increasing GDP would result in high government revenues. Increased public revenues, with subdued public spending. It would result in a significant budget surplus that could be used to reduce public debt. However, the economic fundamentals of this scenario are not currently in Brazil. In the Brazilian economy, which based on the extraction of raw materials and their exports, the international prices of 
these raw materials should increase significantly in order to enhance GDP dynamically. The limatiion of this study should be empasized i.e., other factors and improvements in the output of the Brazilian economy should be improved, but a separate study would be needed to detail them.

Otherwise, privatization of state-owned enterprises is theoretically a suitable tool. It is no longer a realistic option, but an unfounded plan, as the state of international financial markets has changed significantly over the past 1-2 years. This change can be described as the end of cheap loans and lowinterest government bonds, and global economic activity has declined significantly. There is not enough money to invest in the international financial world as it used to be. Brazilian state-owned enterprises that privatized are no longer expected to have such high demand as they would have been 1-2 years before. Also, if only moderate demand expected, it will be reflected in a negative direction in the prices paid to these state-owned enterprises. The other problem with the expected revenues is that a large number of state-owned enterprises to be privatized by the Brazilian government will be a kind of supply dumping that will lead to the depreciation of the shares. It should also be borne in mind that the total consideration received for state property can not be used solely to repay public debt. According to the international experience of privatizations, part of the consideration received for state assets should be used for the reorganization of companies in lousy condition. It was very strongly the case in the transition of the Central and Eastern European (CEE) countries, but this was not true in the case of Greece during the subprime crisis.

Part of the privatization proceeds will certainly reduce Brazilian government debt. It will be much needed for the country's public finances, as the financing of the remaining debt will become more difficult soon. Today, demand for emerging markets, for example, Brazilian government securities, has drastically dropped, which may cause debt financing tensions, as investors will avoid high-risk government securities. International markets nowadays characterized by risk-averse sales behaviour. International investors who have so far purchased government securities from emerging countries because of their high yields are now selling them, especially government bonds in the most vulnerable countries. This wave of sales is on the Brazilian debt market. Brazil was one of the highest interest rates on its government bonds in international comparison. In recent years, the rate has fallen to 6.5 per cent of Brazil's annual GDP, which is still a significant burden on the budget. However, due to the changes in the global money market discussed above, the country's interest rates on Brazilian government securities should be raised soon in order to be bought by investors. However, this increase in interest rates will be even more burden than it is typical today in Brazil's public finances.

\section{Concluding remarks}

Finally, a non-macroeconomic factor mentioned that could make it difficult for the Brazilian government to implement its grandiose privatization plan. It is nothing more than a social opposition to the privatization of public companies. When the state sells its entrepreneurial property, it sells a social asset that comes from the citizens' community contributions and tax payments. In privatization, members of society can rightly feel that something comes to the property of others. It can trigger their resistance to privatization. Particularly neuralgic is the privatization of utilities and the privatization of infrastructure assets, airports, harbours that can serve large-scale consumer needs. There are more 
and more examples of this in both developed and developing countries. Such social resistance has emerged recently, in Greece, Slovenia, New Zealand and Brazil. In these social resistances, nationalist overtones also used, and dissatisfaction with the sale of the country is the responsibility of the decision-makers. However, a more detailed analysis of this is much more relevant to sociology and political science than to economics.

\section{References}

[1] Barr, N. (1987) The Economics of the Welfare State, Weidenfeld and Nicholson, London. Állami beavatkozás. In: Csaba I.- Tóth I. Gy. (eds.): A jóléti állam politikai gazdaságtana, Budapest: Osiris, DOI: https://doi.org/10.1017/S0047279400017074

[2] Barr, N. (1992) Economic Theory and Welfare State: A Survey and Interpretation. Journal of Economic Literature, vol. 30. Issue 2, 1992, 741-803.

[3] Samuelson, P. A. - Nordhaus, W. D. (2012) Közgazdaságtan, III. kötet, Budapest, Akadémiai Kiadó.

[4] Privatization Barometer (2017) The PB Report 2015-16, Retrieved May 22, 2019, from http://www.privatizationbarometer.com/PUB/NL/5/9/PB_AR2015-2016.pdf

[5] World Bank (1997) Privatization and Restructuring in Central and Eastern Europe, Retrieved May 18, 2019, from http://siteresources.worldbank.org/EXTFINANCIALSECTOR/Resources/28288413033 27122200/123pohl.pdf

[6] Megginson, W. L. - Netter, J. M. (2001) From state to market: A survey of empirical studies on privatization, Journal of Economic Literature, Vol. 39, No. 2, June 2001:1-88., DOI: $10.1257 /$ jel.39.2.321

[7] Török, L. (2018) Ireland before and after the Crisis, Authoritative but Hazardous Structural Reforms in Financial Crisis Management, Journal of Public Finance Published Quarterly, Volume LXIII. 254-274.

[8] Estrin, S. - Pelletier, A. (2018) Privatization in Developing Countries: What Are the Lessons of Recent Experience?" The World Bank Research Observer, Volume 33, Issue 1, February 2018, 65-102., DOI: https://doi.org/10.1093/wbro/lkx007

[9] Jeffry, D. - Ossowski, R. - Richardson, T. - Barnett, S. (2000) Fiscal and Macroeconomic Impact of Privatization, IMF Occasional Paper 194, 1-49., Retrieved May 21, 2019, from https://www.imf.org/external/pubs/nft/op/194/index.htm 
[10] Canuto, O. (2018) How to FiHx Brazil's Economy, Project Syndicate, Retrieved April 30, 2019, from www.project-syndicate.org/commentary/brazil-election-economic-reformfiscal-productivity-by-otaviano-canuto-2018-10?barrier=accesspaylog

[11] Tradingeconomics (2019) Brasil indicators, Retrieved May 19, 2019, from https://hu.tradingeconomics.com/brazil/indicators

[12] Ricz, J. - Nagy, S. GY. (2016). A brazil gazdasági válság: helyzetkép, okok és kiutak, Külügyi Szemle, 2016 ősz, 94-120.

[13] Török, L. (2012) A magyar államadósság lehetőségei és lehetetlenségei, Competitio, 2012. december, XI. évfolyam, 2. szám, 26-42. DOI: https://doi.org/10.21845/comp/2012/2/2

[14] CEPR (2017) Brazil's Enormous Interest Rate Tax: Can Brazilians Afford It? Center for Economic and Policy Research, Retrieved May 20, 2019, from http://cepr.net/images/stories/reports/brazil-interest-rates-2017-04.pdf

[15] The Rio Thimes (2017) Brazil Announces Massive R\$44 Billion Privatization Plan, Retrieved May 21, 2019, from https://riotimesonline.com/brazil-news/riobusiness/brazil-announces-massive-privatization-plan/ 